\title{
SUBLESSEES, MORTGAGEES AND THE DOCTRINE OF TULK V MOXHAY
}

\author{
Alan Dowling, School of Law, Queen's University Belfast
}

The doctrine of Tulk v Moxhay is an illustration of how complexity can be bred from simplicity. When Lord Cottenham granted an injunction to restrain Mr. Moxhay from building on Leicester Square in contravention of a covenant which his predecessor in title had made with Mr. Tulk, he did so on the basis that Moxhay had bought the land with knowledge of the covenant, and should not be allowed to act in defiance of it. Had the law continued on that basis, it would, whatever other objections might have been levelled against it, have had the merit of simplicity. Unfortunately, development of the doctrine in later decisions led to the present state of the law in which to describe the doctrine as simple would be a misrepresentation. One factor leading to the complexity that now surrounds the doctrine is the requirement that a plaintiff seeking to rely on the doctrine must show that he has land for the protection of which the covenant was made. That requirement is the background to the present discussion. What follows is an attempt to address the questions whether a lessor can rely on the doctrine to restrain a sublessee from acting in contravention of the covenants made by the lessee in the lease, and whether a mortgagee or chargee can rely on the doctrine to prevent a successor in title to a borrower from acting in breach of covenants by the borrower contained in the mortgage or charge. The authorities suggest an affirmative answer in each case. One leading text however has suggested that that view may be open to question. ${ }^{1}$

\section{The Basis of the Doctrine}

The dictum of Jessel M.R. in London \& South Western Railway Co. v Gomm,$^{2}$ that the doctrine of Tulk $\mathrm{v}$ Moxhay ${ }^{3}$ is either an extension in Equity

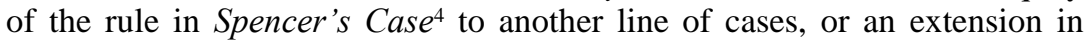
Equity of the doctrine of negative easements, is well known. Though the pedigree of the doctrine may be doubtful, for the first half century of its life the doctrine's parentage did not cause any trouble. The doctrine enabled those to whom promises had been made, that land would not be used in particular ways, or that activities would not take place on land, to obtain injunctions to restrain persons who had not made those promises from acting inconsistently with them. Initially, the doctrine was based simply on the defendant having notice of the covenant. Later, the land was seen as subject to an equitable burden, and those who later acquired the land were affected by the burden, unless they were bona fide purchasers of a legal estate in the land without notice of the covenant. ${ }^{5}$ On either view, the absence of notice

1 Megarry \& Wade, The Law of Real Property (5th ed., 1984) p.776. The relevant sentence of the text does not appear in the current edition of the work.

2 (1881) 20 Ch. D. 562, at 583.

3 (1848) 2 Ph. 774; 1 H. \& Tw. 105.

4 (1583) 5 Co. Rep. 16a.

5 For a chronological review of the authorities, marking the developments, see the judgment of Scrutton J. in London County Council v Allen [1914] 3 K.B. 642. 
meant that the successor took the land free of the obligation. Where however notice existed, the Court of Chancery provided relief where none was available at law, as to the Courts of Common Law the burden of a covenant would not (save in cases where the relation of landlord and tenant existed) affect anyone other than the person who had undertaken the obligation.

\section{Development of the Doctrine}

As time went by however, the simplicity of the doctrine disappeared. The doctrine came to be limited to preventing breaches only of restrictive covenants, i.e. covenants not to do something. ${ }^{6}$ In cases where the covenant required the covenantor to do something, the doctrine was of no use to a plaintiff seeking to compel a successor to the covenantor to carry out the terms of the covenant. A further development of the doctrine was the requirement that the plaintiff, if he was not the original covenantee, had to show that the benefit of the covenant had come into his hands in one of the various ways recognised by the courts. ${ }^{7}$ The most important development in the doctrine however, for the purposes of the discussion which follows, was the requirement, established shortly after the turn of the twentieth century, that a plaintiff could not succeed under the doctrine unless he had land for the protection of which the covenant was made. No longer would a successor in title to a covenantor be enjoined from acting in contravention of a restrictive covenant simply on the basis that he was affected by notice of the covenant when he acquired the land: if the plaintiff did not have land, Equity would afford no assistance against a defendant who was not the original covenantor.

The last of the developments of the doctrine in Tulk v Moxhay mentioned in the preceding paragraph indicates the similarity noted by Jessel M.R. between the doctrine and the law of easements. Just as there can be no easement in gross, ${ }^{8}$ so it was held that a plaintiff seeking to enforce a covenant under the doctrine in Tulk v Moxhay would not be able to succeed in the absence of land benefited by the covenant. The requirement of dominant and servient tenements for an easement to exist now had its counterpart in the doctrine of Tulk $\mathrm{v}$ Moxhay. The question for discussion here is whether the effect of this development of the doctrine is to prevent lessors and mortgagees from obtaining injunctions in the situations mentioned. There are authorities that a lessor may succeed under the doctrine in Tulk v Moxhay in restraining a sublessee from acting in breach of restrictive covenants in the lease; likewise, decisions exist in which mortgagees have been successful in obtaining injunctions against successors in title to the mortgagor; but in the main these pre-date the establishment of the requirement that the plaintiff have land, and in those cases determined after such requirement was established there has been little explanation of how the situation of the parties to the action can be accommodated with the requirement that the plaintiff have land for the protection of which the covenant was made.

${ }^{6}$ Haywood v Brunswick Permanent Building Society (1881) 8 Q.B.D. 403.

7 Megarry \& Wade, The Law of Real Property (6 $6^{\text {th }}$ ed., 2000) para.16.059.

8 Rangeley v Midland Railway Co. (1868) 3 Ch. App. 306. 


\section{The Protection of Land}

The requirement that the plaintiff have land in order to be able to rely on the doctrine of Tulk v Moxhay was established by the Court of Appeal in Formby v Barker ${ }^{9}$ and London County Council v Allen. ${ }^{10}$ In the former case, the administratrix and legatee of a covenantee brought an action against the successor in title to the covenantor to prevent the defendant acting in contravention of a restrictive covenant contained in a conveyance by which the covenantee had sold his land to the covenantor. The action failed. The judgment of Vaughan Williams L.J. proceeds on the basis of a distinction between covenants that are personal or collateral and covenants that benefit land of the covenantee. The Lord Justice owned to being unable to find any case in which, after the sale of the whole of an estate in land, the benefit of a restrictive covenant had been enforced by injunction against the assignee of the purchaser at the instance of a plaintiff having no land retained by the vendor, and referred to the absence in the case before him of any relation of dominancy and serviency of lands which would enable an action to be brought against a person not a party to the original contract. The covenant on which the plaintiff relied "ha[d] not been entered into for the benefit of any land of the vendor, or of any land designated in the conveyance," 11 and would not pass to the heirs of the vendor, notwithstanding that the covenant was made with the covenantee "his heirs, executors and administrators". The terminology of dominancy and serviency clearly echoes the language of the law of easements, and, with the reference to retained land, suggests that in the absence of two distinct parcels of ground, the one burdened by the covenant, the other enjoying the benefit, the doctrine will not apply. That appears also from London County Council v Allen, in which a local authority sought an injunction to restrain the successor in title of a landowner who had covenanted with the authority not to build on his land from acting in breach of the covenant. Refusing the application, Buckley L.J. explained that " $[\mathrm{t}] \mathrm{he}$ doctrine is that a covenant not running with the land, but being a negative covenant entered into by an owner of land with an adjoining owner, binds the land in equity and is enforceable against a derivative owner taking with notice. The doctrine ceases to be applicable when the person seeking to enforce the covenant against the derivative owner has no land to be protected by the negative covenant. The fact of notice is in that case irrelevant." 12 Developing the dictum of Jessel M.R. in London and South Western Railway v Gomm, Buckley L.J. went on to say: "[t]he doctrine is either an extension in equity of the doctrine in Spencer's Case (in which ownership of land by both covenantor and covenantee is essential) or an extension in equity of the doctrine of negative easements, a doctrine applicable not to the case of easements in gross, but to an easement enjoyed by one land upon another land. Where the covenantee has no land, the derivative owner claiming under the covenantor is bound neither in contract nor by the equitable doctrine which attaches in the case where there is land capable of enjoying the restrictive covenant." 13

\footnotetext{
9 [1903] 2 Ch. 539.

10 [1914] 3 K.B. 642.

11 [1903] 2 Ch. 539, at 552.

12 [1914] 3 K.B. 642, at 654.

13 ibid., at 660 .
} 


\section{Lessors and Sublessees}

The attraction of the doctrine of Tulk v Moxhay for lessors seeking to enforce restrictive covenants contained in leases against sublessees can be seen from a consideration of the principles concerning the running of the burden of leasehold covenants. At common law the burden of a covenant undertaken by a lessee would be enforced against assigns of the lessee, so long as the covenant touched and concerned the land. ${ }^{14}$ If therefore an assignee of the lease acted in violation of a covenant undertaken by the lessee, the lessor was able to invoke whatever remedies were available, such as damages or forfeiture. Where however the breach was the result of an act on the part of a sublessee, the lessor's ability to remedy the situation was not assured, as a sublessee was not an assign of the lessee so as to be liable on the lessee's covenants. ${ }^{15}$ If the covenant was not an absolute covenant on the part of the lessee (e.g. "the lessee covenants the premises will not be used for ..."), then unless the acts of the sublessee could be laid at the door of the lessee, so that there was a breach by the latter, the lessor had no cause of action. ${ }^{16}$ Hence the use of covenants whereby the lessee promised not only not to do certain acts, but also not to permit or suffer such acts to be done, and the various cases in which the question was whether the lessee could be said to have permitted or suffered the carrying out by sublessees of acts prohibited by the lessee's covenant. ${ }^{17}$ In cases where the answer was that the lessee had not permitted or suffered the acts, then there was no breach by the lessee, and therefore no right of action based on breach of covenant against the lessee for damages, forfeiture or anything else. The possibility of an action against the sublessee in such circumstances would obviously be of great benefit to the lessor.

The doctrine of Tulk $\mathrm{v}$ Moxhay provided just such a possibility. Sublessees, acquiring land which was burdened in Equity by restrictive covenants undertaken by the lessee, took the land subject to that burden unless they were bona fide purchasers for value of a legal estate without notice of the burden. Bona fide purchasers of a legal estate they might well be, but absence of notice was another matter. In most cases sublessees would be fixed with constructive notice of the covenants undertaken by the lessee, and

14 Spencer's Case (1583) 5 Co. Rep. 16a. For the enforceability of covenants in leases made in England and Wales after 1995 see now Landlord and Tenant (Covenants) Act 1995. In Ireland the ability of lessors to enforce covenants undertaken by lessees against assignees of the lease is governed by section 12 of Deasy's Act.

15 Holford v Hatch (1779) 1 Doug. 183. See generally Re Town Investments Ltd. 's Underlease [1954] 1 All E.R. 585; Hand v Blow [1901] 2 Ch. 721; South of England Dairies Ltd. v Baker [1906] 2 Ch. 631.

16 Contrast Bryant v Hancock \& Co. Ltd. [1898] 1 Q.B. 716 (affd. on other grounds [1899] A.C. 442) and Palethorpe v Home Brewery Co. Ltd. [1906] 2 K.B. 5. See also Mumford v Walker (1901) 85 L.T. 518.

17 Hall v Ewin (1897) 37 Ch. D. 74; Wilson v Twamley [1904] 2 K.B. 99; Berton $\mathrm{v}$ Alliance Economic Investment Co. Ltd. [1922] 1 K.B. 742; Atkin v Rose [1923] 1 Ch. 522; Barton v Reed [1932] 1 Ch. 362; Borthwick-Norton v Romney Warwick Estates Ltd. [1950] 1 All E.R. 798; Tophams Ltd. v Earl of Sefton [1966] 1 All E.R. 1039. See also Prothero v Bell (1906) 22 T.L.R. 370 (part of covenant held absolute). 
the rule in Patman v Harland ${ }^{18}$ ensured that even where sublessees were prevented from seeing the lease containing the covenants, they would be fixed with notice of the covenants nonetheless. So long therefore as notice was the essential element of the rule in Tulk $\mathrm{v}$ Moxhay, lessors could look forward to injunctive relief to prevent sublessees acting in contravention of the terms of a restrictive covenant undertaken by the lessee, whether or not any remedy existed against the lessee himself.

And so it proved. Leaving aside cases ${ }^{19}$ in which the lessor was possessed of adjacent land, Parker v Whyte, ${ }^{20}$ Tritton v Bankart, ${ }^{21}$ Hall $\mathrm{v}$ Ewin $^{22}$ and Teape $\mathrm{v}$ Douse ${ }^{23}$ are all instances in which the court granted an injunction to a lessor to prevent a sublessee acting in breach of a covenant in the lease on the basis that the sublessee had notice of the covenant (Tritton $\mathrm{v}$ Bankart and Hall $\mathrm{v}$ Ewin being concerned more with whether an injunction should be granted against the lessee as well as against the sublessee). Whether, following the decisions in Formby v Barker and London County Council v Allen, these cases remain good law in the case of a lessor who has demised the whole of his land, is the problem. ${ }^{24}$ There are few authorities in which the point has been discussed. In Northern Ireland Carriers Ltd. v Larne Harbour Ltd. ${ }^{25}$ the point was raised, but in the event Murray J. did not have to determine it, as the covenant in question was held to be personal to the lessee, so that the sublessee would not be restrained from acting in contravention of it even if the lessor's interest was sufficient to satisfy the requirements of the doctrine in Tulk v Moxhay. In Hemingway Securities $L t d$. v Dunraven Ltd. ${ }^{26}$ an injunction was granted in favour of a lessor requiring a sublessee to surrender a sublease which had been made in breach of a covenant in the lease, the argument that "it is well settled that a restrictive covenant for the benefit of the landlords' reversion counts for the purposes of the doctrine of Tulk v Moxhay" being accepted.

\section{Actions by Mortgagees}

The doctrine of Tulk v Moxhay has also been successfully used by mortgagees to restrain someone other than the mortgagor from acting in contravention of a restrictive covenant made by the mortgagor. In this context too the question arises whether following the decisions in Formby v Barker and London County Council v Allen the position has changed. In John Brothers Abergarw Brewery Co. v Holmes ${ }^{27}$ a brewery company

18 (1881) 17 Ch. D. 353.

19 Evans v Davis (1878) 10 Ch. D. 747; Craig v Greer [1899] 1 I.R. 258.

20 (1863) 1 H. \& M. 167.

21 (1887) 56 L.T. 306.

22 (1887) 37 Ch. D. 74

23 (1905) 92 L.T. 319.

24 In England and Wales, where the lease has been made after the coming into force of the Landlord and Tenant (Covenants) Act 1995, the problems identified above are resolved, section 3(5) of the Act providing that a restrictive covenant on the part of the lessee may be enforced against anyone who is the owner or occupier of the demised premises, thereby allowing actions against sublessees.

25 [1981] N.I. 171.

26 (1994) 71 P. \& C.R. 30.

27 [1900] 1 Ch. 188. 
holding a mortgage on a public house succeeded in enforcing a covenant made by the borrower to take supplies of beer only from the mortgagee against someone claiming through the borrower. The case was decided before the requirement that the plaintiff have land was established, so does not answer the question. Of more assistance is Regent Oil Co. Ltd. v J. A. Gregory (Hatch End) $L t d .{ }^{28}$ in which the question was whether a successor in title to a borrower who had covenanted with a lender in a charge by way of legal mortgage to take supplies of fuel only from the lender was bound by the covenant under the doctrine in Tulk $\mathrm{v}$ Moxhay. At first instance UngoedThomas J. was of the view that there were formidable difficulties in the argument that the successor was liable, but was able to determine the case on another point. On appeal however Harman L.J. saw no such difficulties with the application of the doctrine, saying that "a mortgagee has of necessity an interest in the land the subject-matter of the charge, which I think he is entitled to protect by covenants relating to the user of it." ${ }^{29}$ In Canada a similar view was expressed by White J. in Cities Service Oil Co. Ltd. v Pauley. ${ }^{30}$

\section{Issues Arising}

A number of matters arise from the foregoing discussion which call for consideration in addressing the difficulties of the application of the doctrine to the case of a lessor seeking to prevent a sublessee from acting in contravention of a covenant contained in the lease, and that of a mortgagee seeking to prevent a successor in title of the borrower from acting in contravention of a covenant contained in the mortgage. These may be formulated in a number of questions. First, do lessors and/or mortgagees in fact have land within the meaning of Formby v Barker and London County Council v Allen, so that there is no difficulty in their relying on the doctrine? Secondly, if not, ought they or either of them to be protected by the doctrine? And thirdly, if the answer to that is yes, are lessors and/or mortgagees to be considered simply as exceptional cases, or is there a general principle on which the doctrine can be explained, accommodating lessors and/or mortgagees rather than seeing them as exceptional cases to whom the requirement in Formby v Barker and London County Council v Allen that the plaintiff have land does not apply?

Answering the first of these questions requires further consideration of what is meant by "land" in Formby v Barker and London County Council v Allen. ${ }^{31}$ In later cases, when the question was whether the plaintiff met the requirements of the doctrine of Tulk $\mathrm{v}$ Moxhay, the courts were concerned more with whether it was necessary that the plaintiff's land be defined in the

[1965] 2 All E.R. 90; [1965] 3 All E.R. 673.

29 [1965] 3 All E.R. 673, at 680.

30 [1931] O.R. 685.

31 For the same question arising in a different context, see $P$. \& A. Swift Investments v Combined English Stores Group plc. [1989] A.C. 632 (whether landlord's reversion itself "land" so as to allow successor in title to landlord to enforce surety covenant where benefit not expressly assigned with reversion). 
deed containing the covenant, ${ }^{32}$ or whether the wording of the covenant was sufficient to mean that the benefit of the covenant had been annexed to that land ${ }^{33}$ or whether, if the land and the benefit of the covenant had been separated, their later reunion in the hands of the plaintiff cured the difficulty ${ }^{34}$ than with the question whether the doctrine applies where what the plaintiff is relying on is not an adjacent parcel of land but an interest in the land burdened by the covenant. The question arises because of the two possible meanings of the word "land", viz., signifying either a parcel of land ("my land lies adjacent to yours") or as signifying certain rights of property, including incorporeal rights. Section 2 of the Conveyancing and Law of Property Act 1881 is an example of the word being defined to include both meanings. A similar case exists under the Law of Property Act 1925. ${ }^{35}$ Thus the owner of a easement has something which itself is "land" ${ }^{36}$ The same ambiguity arises in connection with use of the word "estate", which may mean either an area of land ("the Dulwich estate") or describe rights in land (e.g. "an estate in fee simple"). Although Williams L.J.'s reference in Formby v Barker to "the whole of an estate in land" might suggest that the terms "estate" and "land" must signify different things, it seems from the reference elsewhere in the judgment to the vendor having "no contiguous estate" that the Lord Justice's references both to land and to an estate refer to parcels of land. The same possible construction that "land" in Buckley L.J.'s judgment in London County Council v Allen includes the rights of a lessor or mortgagee in land subject to a lease or mortgage derives some support from the reference in the judgment to the doctrine in Spencer's Case "in which ownership of land by both covenantor and covenantee is essential". In the context of Spencer's Case this can only be a reference to the estates held by landlord and tenant rather than two different parcels of land. The argument that an estate in the burdened land suffices for the purposes of the doctrine of Tulk v Moxhay appears to be displaced by the references elsewhere in Buckley L.J.'s judgment to adjoining land, meaning clearly an adjacent parcel of land. It seems clear from the reference in Buckley L.J.'s judgment to covenants entered into between adjoining owners, and from his reference to Lord Cottenham's statement in Tulk v Moxhay that unless the court enforced the covenant it would be impossible for a landowner to sell part of his land without the risk of rendering what he retained worthless, that what Buckley L.J. meant by the plaintiff having land was that he had a plot of ground separate from the land burdened by the covenant. If that is so, then lessors seeking to enforce restrictive covenants in the lease against sublessees should be unable to do so unless they have land adjacent to the land demised by the lease. The same will be the case for mortgagees and chargees unless they have land adjacent to the land which is the subject of

32 Renals v Cowlishaw (1879) 11 Ch. D. 866; Miles v Easter [1933] Ch. 611; Newton Abbot Co-Operative Society Ltd. v Williamson \& Treadgold Ltd. [1952] 1 All E.R. 279; Marten v Flight Refuelling Ltd. [1961] 2 All E.R. 696.

33 Renals v Cowlishaw (1879) 11 Ch. D. 866; Miles v Easter [1933] Ch. 611; Newton Abbot Co-Operative Society Ltd. v Williamson \& Treadgold Ltd. [1952] 1 All E.R. 279; Shropshire C.C. v Edwards (1983) 46 P. \& C.R. 270.

34 Lord Northbourne v Johnston \& Son [1922] 2 Ch. 309; Chambers v Randall [1923] 1 Ch. 149.

35 Section 205(1)(ix).

36 Willies-Williams v National Trust (1993) 65 P. \& C.R. 359. 
the security. Even then however, their ability to sue under the doctrine of Tulk v Moxhay is not established unless the covenant was made with the lessor or mortgagee for the benefit of the adjoining land, rather than with the lessor simply as lessor of the demised property or mortgagee simply as lender.

The second question identified above is whether lessors and/or mortgagees ought to be protected by the doctrine. As a matter of policy, it is thought the answer should be yes in each case. In the case of a mortgagee, the mortgage debt is protected by the land on which it is secured, and maintenance of the value of the land is clearly therefore important. The view, of Harman L.J. in Regent Oil Co. Ltd. v J. A. Gregory (Hatch End) Ltd. and of White J. in Cities Service Oil Co Ltd. v Pauley, that a mortgagee has an interest which he should be entitled to protect by covenants must surely be right. The same argument can be made for extending the protection of the doctrine to a lessor who does not retain any adjacent land. As with the mortgagee, the lessor has a direct monetary interest in the land in the form of the rent reserved by the lease. While the rent will be payable whether any covenant in the lease is observed or not, if the value of the land falls because it is used in breach of covenant the lessor may find that any future lease he might make would attract a lower rent. Further, the lessor's estate is protected under the law of landlord and tenant, and it would seem odd if it did not qualify for protection under the doctrine of Tulk $\mathrm{v}$ Moxhay.

Turning to the third question, if the cases in which lessors have been successful in obtaining injunctions against sublessees and mortgagees have obtained orders against successors to the mortgagor are to be upheld following Formby v Barker and London County Council v Allen, some explanation must be offered as to how the cases can be reconciled with the view that the doctrine of Tulk $\mathrm{v}$ Moxhay will not assist a plaintiff who does not have land for the protection of which the covenant was made. One possible explanation is that both lessor and mortgagee have an estate in the land burdened by the covenant, and that ownership of an estate in the burdened land is a sufficient alternative to ownership of adjoining land. A second possibility is that suggested in Hemingway Securities, viz., that the lessor's reversionary interest counts for the purposes of the doctrine.

\section{An estate in the burdened land}

Protection of a plaintiff under the doctrine of Tulk v Moxhay on the basis that the plaintiff has an estate in the land of the defendant would follow naturally from the explanation that the doctrine has its roots in Spencer's Case. There the judges resolved that the burden of a covenant would be enforceable by a lessor against a successor to the lessee if the covenant touched and concerned the thing demised, i.e. the demised land. Some years before Spencer's Case, Parliament had determined that successors in title to the lessor should have the same remedies as had been enjoyed by the lessor himself. ${ }^{37}$ The result was that in the context of landlord and tenant, benefit and burden of covenants ran with the estates of the parties in the land demised by the lease. If ownership of an estate in land is likewise sufficient for the purposes of the doctrine of Tulk $\mathrm{v}$ Moxhay, then lessors and mortgagees will be protected,

37 Grantees of Reversions Act 1540. 
but a problem exists for lenders whose security takes the form of a charge on the land rather than a mortgage. A charge confers no estate in the land on the lender, merely rights over the land exercisable in the event of the borrower's default. It is thought unlikely that a court of Equity would be keen to allow mortgagees to take advantage of the doctrine and at the same time deny relief to chargees on the basis that the former have an estate in the land but the latter do not. The form of the security taken by the lender may well be dictated by circumstances which have little to do with the substance of the transaction, and it would be harsh to say that the form of the transaction alone should mean that one lender has a remedy while another does not. If that view is correct, then the view that the ownership by the plaintiff of an estate in the burdened land is what allows lessors and secured lenders to rely on the doctrine in Tulk v Moxhay can be discounted.

\section{A reversion}

The possibility needs to be considered whether decisions in which the doctrine in Tulk v Moxhay has been successfully invoked by plaintiffs who do not have adjacent land can be upheld on the basis that the plaintiff's reversionary interest is sufficient. It is certainly arguable that if a lessor cannot prevent a sublessee from acting in breach of covenants in the lease, the lessor may, when the lease falls in, recover possession of something less valuable on account of the unlawful activity, and that accordingly he should be protected by the doctrine in Tulk $\mathrm{v}$ Moxhay. The case of vendor and purchaser is distinguishable in that the vendor has no right or possibility of possession in the future of the property he has sold. There are however problems with such a view. First, the reversionary interest retained by the lessor may be nominal only, as where the plaintiff is himself a lessee, and the (sub)lease he has made is (in practical terms) for the whole of the term for which he is entitled to the land. To uphold the applicability of the doctrine of Tulk v Moxhay in the case of lessor and sublessee on the ground of the reversionary interest the lessor has, but a vendor does not, may be unjust in such cases. The second problem is that acceptance of the argument would mean that the doctrine will not protect a mortgagee who has no reversionary interest corresponding to that of a lessor. The same considerations as to protection of the interest of a mortgagee who may on default of the borrower obtain possession of land which has been devalued as a result of the failure to observe covenants undertaken by the borrower in the mortgage apply in this instance.

\section{Exceptional cases}

A third possible explanation for allowing lessors and mortgagees to succeed under the doctrine of Tulk $\mathrm{v}$ Moxhay following the decisions in Formby v Barker and London County Council v Allen is that theirs are cases to which the limitations of the doctrine contained in those cases do not apply; in other words, that actions by lessors and mortgagees are simply exceptional cases. ${ }^{38}$ Apart however from there being nothing in London County Council v Allen to suggest the existence of any exceptional cases, if that is the correct

38 A number of exceptional cases do exist in which statutory provisions enable plaintiffs to enforce restrictive covenants despite the absence of land: see Megarry \& Wade, op. cit. $\left(6^{\text {th }}\right.$ ed., 2000) para.16.047. 
analysis, it is arguable that such plaintiffs can rely on the doctrine to prevent breach of covenants which are purely personal or collateral (to use the terminology in Formby v Barker). That may be undesirable, for reasons considered below. An alternative argument is that the type of covenants which are enforceable under the doctrine is limited by the relationship between the parties. In the case of a lessor relying on the doctrine against a sublessee, an obvious limitation would be that such covenants must "touch and concern the thing demised", i.e. to apply the same test as existed at common law in the case of covenants enforceable against successors to the lessee. In the case of a mortgagee relying on the doctrine against a successor to the mortgagor, it might be thought appropriate that only covenants having reference to the security created might be enforceable under the doctrine.

The cases in which mortgagees have been successful in enforcing covenants against defendants who were not the covenantors seem however to suggest that covenants enforceable under the doctrine are not limited to ones protecting the lender's interest as lender. All three cases concerned solus ties. In John Brothers Abergarw Brewery Co. v Holmes the covenant required the borrower to take supplies of beer solely from the lender; Regent Oil Co. Ltd. v J. A. Gregory (Hatch End) Ltd. and Cities Service Oil Co. Ltd. $\mathrm{v}$ Pauley concerned supplies of fuel. Mortgage cases involving such covenants have usually proceeded on the basis that the covenants were collateral to the security, the question for the court being whether a collateral benefit was an unlawful clog on the mortgagor's equity of redemption. ${ }^{39}$ In contrast, in landlord and tenant cases, covenants by lessees to take supplies solely from the lessor have been held enforceable by and against successors in title to the original parties on the basis that the covenants touch and concern the land. ${ }^{40}$ Harman L.J. in Regent Oil Co. considered the landlord and tenant cases analogous to the case before him. The result would appear therefore to be that mortgagees can rely on the doctrine to enforce covenants which are made for purposes other than the protection of the mortgagee's interest as lender. In Regent Oil Co. Harman L.J. pointed out that the object of the plaintiff in entering the transaction with the borrower was to find an outlet for its products rather than a security for its money. Similarly, in John Brothers Abergarw Kekewich J. found that the object of the covenant was to protect the lender's business. In each case the plaintiff was a mortgagee, but in neither was the covenant enforced primarily concerned with protection of a mortgage debt.

\section{Reconsideration}

It seems therefore that explanations that lessors and mortgagees are able to rely on the doctrine of Tulk v Moxhay either because they have an estate in the land, or a reversionary interest, or because theirs are exceptional cases to which the limitations imposed by Formby v Barker and London County

39 See, e.g. Biggs v Hoddinott [1898] 2 Ch. 307; Noakes \& Co. Ltd. v Rice [1902] A.C. 24; Morgan v Jeffreys [1910] 1 Ch. 620. For the validity of collateral advantages see G. \& C. Kreglinger v New Patagonia Meat \& Cold Storage Co. Ltd. [1914] A.C. 25.

40 See Clegg v Hands (1890) 44 Ch. D. 503; White v Southend Hotel Co. [1897] 1 Ch. 767; Manchester Brewery Co. v Coombs [1901] 2 Ch. 608; Caerns Motor Services Ltd. v Texaco Ltd. [1995] 1 All E.R. 247. 
Council v Allen do not apply, are, for one reason or another, unsatisfactory. If lessors and mortgagees are still entitled to the benefit of the doctrine after those decisions, some other explanation must be suggested. One of course would be that Formby v Barker and London County Council v Allen were wrong in establishing a requirement that the plaintiff have land for the protection of which the covenant in question was made. ${ }^{41}$ One comment that can be made in support of that proposition is that in neither case did the court review all the authorities which have a bearing on the question. In London County Council v Allen Scrutton J. pointed out that neither Catt v Tourle ${ }^{42}$ nor Luker $\mathrm{v}$ Dennis ${ }^{43}$ had been mentioned in Formby v Barker. In each of those cases a brewery company had been successful in obtaining an injunction to enforce a solus tie despite the apparent absence of any land for the benefit of which the covenant had been made. The cases were however discussed in London County Council v Allen itself, Buckley L.J. saying that they "undoubtedly create a difficulty", before going on to say that statements in the former were inconsistent with later authorities and that the latter could not be relied on as accurately stating the law. More significantly for the purposes of the present discussion, there is no mention in either Formby v Barker nor London County Council v Allen of the various cases in which lessors and mortgagees had successfully relied on the doctrine, nor is there any discussion of the operation of the doctrine in those situations.

\section{Rationale}

Leaving aside the question whether as a matter of law the decision in London County Council v Allen is correct, the rationale of the requirement that the plaintiff have land for the doctrine of Tulk v Moxhay to apply is said to be that there must be some identifiable landowner with whom it is possible to bargain for a discharge of the covenant, or that the requirement operates as a test of standing, ensuring that plaintiffs have a legitimate interest in the enforcement of the covenant. ${ }^{44}$ Of the two, the latter seems the better explanation, as a release of the covenant can be effected by the person with the benefit of it, whether or not that person has land, and the ability of the covenantor to identify the person who is entitled to enforce the covenant will not be much assisted by the knowledge that it must be someone who owns land nearby. On the other hand, by enforcing only those covenants which are intended to benefit land of the covenantee, the law ensures that land is not indefinitely burdened by obligations which may be capricious. ${ }^{45}$ A similar

41 For discussion of Formby v Barker and the earlier authorities leading to the emergence of the requirement that the plaintiff have land see Gardner, "The proprietary effect of contractual obligations under Tulk v Moxhay and De Mattos v Gibson" (1982) 98 L.Q.R. 279, the author commenting at p.307 that "the conclusion of appurtenance in restrictive covenants is drawn from an analogue, the easement, which seems no more compelling than other rights which lack that requirement; the presence of the requirement in the analogue itself is questionable in derivation and policy; and the resultant requirement in restrictive covenants is not identical with that in the analogue."

42 (1869) 4 Ch. App. 654.

43 (1877) 7 Ch. D. 227.

44 See Gray \& Gray, Elements of Land Law (4th ed., 2005) para.9.160; Gardner, op. cit. 309.

45 See discussion ibid. 
filtering process exists in the law of easements, so that some rights may exist as easements while others may not, ${ }^{46}$ and in the law of landlord and tenant, so that only covenants having reference to the subject-matter of the lease were at common law enforceable outside the law of contract. ${ }^{47}$ The underlying principle is that incidents of a novel kind cannot be attached to property at the fancy or caprice of any owner. ${ }^{48}$

\section{Protection of Property}

If Formby v Barker and London County Council v Allen are open to the criticism that the views expressed in them were arrived at without consideration of cases in which lessors and mortgagees had successfully relied on the doctrine, and yet some filter should exist, in order to avoid the situation envisaged in Keppell $\mathrm{v}$ Bailey ${ }^{49}$ of incidents of a novel kind being imposed on land, the question is what the test should be. One way of distinguishing lessors and mortgagees on the one hand from vendors on the other, and to say that the former are entitled to protection under the doctrine of Tulk v Moxhay but the latter is not, is that the former have property other than the benefit of the covenant: the mortgagee has a debt which is protected by the land on which it is secured; the lessor has a rent issuing out of the land demised, and will have possession of the demised land itself once the lease falls in. In each case the value of the land is important for the protection of the plaintiff's interest, so that covenants intended to protect the plaintiff's interest by maintaining the value of the land should be enforceable by the plaintiff against subsequent owners of the land. If the doctrine of Tulk $\mathrm{v}$ Moxhay had been based on the protection of property, rather than the protection of one form of property only (adjacent land), lessors and mortgagees would have come within the doctrine so long as the covenant in question had been made for the protection of that property. Some support for such a wider view of the doctrine may in fact be found in Formby v Barker, Romer L.J. saying that if restrictive covenants are entered into with a covenantee, "not in respect of or concerning any ascertainable property belonging to him, or in which he is interested, then the covenant must be regarded, so far as he is concerned, as a personal covenant". ${ }^{50}$

Had the basis of the doctrine of Tulk v Moxhay been the protection of property rather than that which was settled in Formby v Barker and London County Council v Allen, later cases would of course have proceeded differently. Perhaps the most obvious example is the cases in which the question has been whether the covenant in question was made for the protection of land of the plaintiff, or for the protection of the plaintiff's business. Once the protection of land became the touchstone for enforceability of restrictive covenants, that the covenant was made for the protection of a business owned by the plaintiff rather than for the protection of land owned by him became a matter raised by defendants to avoid an

46 See Megarry \& Wade, op. cit. (6 $6^{\text {th }}$ ed., 2000) para.15.022.

47 See ibid., para.18.053.

48 Keppell v Bailey (1834) 2 My. \& K. 517.

49 (1834) 2 My. \& K. 517.

50 [1903] 2 Ch. 539, at 554 (emphasis added). 
injunction. $^{51}$ If the doctrine of Tulk $\mathrm{v}$ Moxhay were applicable where the covenant is made for the protection of property of the plaintiff, then covenants made for the protection of the plaintiff's business would come within it without the need to show that the covenant protects land of the plaintiff as well. ${ }^{52}$ The result would be that cases such as Catt v Tourle and Luker v Dennis, in which covenants imposing solus ties had been enforced by plaintiffs for the protection of whose businesses the covenants had been made, could be upheld, not on the basis of notice, but on the basis that the covenants in question were made for the protection of property owned by the plaintiff.

\section{Conclusion}

So long as the doctrine of Tulk v Moxhay was based simply on the defendant having notice of the covenant, whether the doctrine was an extension of the doctrine of Spencer's Case or an extension of the law of negative easements was of little moment. Formby v Barker and London County Council v Allen mark the point at which identifying the pedigree of the doctrine in Tulk $\mathrm{v}$ Moxhay became important, and in asserting the need for the plaintiff to have land, suggest the courts saw the law of easements rather than the law in Spencer's Case as its natural forebear. That is hardly surprising given the cases in which application of the doctrine had commonly arisen. Tulk $\mathrm{v}$ Moxhay involved the sale of part of the land of the plaintiff and in it Lord Cottenham L.C. had expressed concern about the value of the land retained if the covenant entered by the purchaser were not enforceable against his successor in title. It was this that influenced the court in London County Council v Allen to take the view that a plaintiff having no land could not rely on the doctrine. In taking that view however the courts, wittingly or not, may well have brought about the result that lessors and mortgagees whose only land is their interest in the land burdened by the covenant do not come within the protection of the doctrine. To have stated the requirement in terms that the plaintiff must have property other than simply the benefit of the covenant, for the protection of which the covenant was made, would have preserved the decisions in which lessors and mortgagees had been protected by the doctrine while at the same time have avoided the danger articulated in Keppell $\mathrm{v}$ Bailey that burdens of any kind could be imposed on land which would be enforceable against persons other than the covenantor.

51 Newton Abbot Co-Operative Society Ltd. v Williamson \& Treadgold Ltd. [1952] 1 All E.R. 279; U.B.H. (Mechanical Services) Ltd. v Jones (1985) unrep. (Nicholls $\mathrm{J}$.). The same issue had arisen in cases involving easements: see Moody v Steggles (1879) 12 Ch. D. 261; Copeland v Greenhalf [1952] 1 All E.R. 809.

52 See U.B.H. (Mechanical Services) Ltd. v Jones, supra. 